\title{
KARAKTERISTIK KOMPETENSI SDM: CONTENT ANALYSIS IKLAN LOWONGAN PEKERJAAN SALES PADA E-RECRUITMENT
}

\author{
Sri Nur Kasanah ${ }^{1}$ dan Rosaly Franksiska ${ }^{2}$ \\ Fakultas Ekonomika dan Bisnis, Universitas Kristen Satya Wacana \\ J1. Diponegoro 52-60, Salatiga, Indonesia \\ Email: 212013238@student.uksw.edu ${ }^{1}$,rosaly.franksiska@staff.uksw.edu²
}

\begin{abstract}
Low interest ofjob seekers to fill the job positionsas sales allegedly due to high competency criteria set by the company for sales jobs. Given this assumption, researcherwas interested in analyzing the competencies required by the company to prospective employeesin the field of sales, published on job sites in the online media. With this research, it is expected to provide benefits for job seekers to explore the competencies needed by the company on the sales. Data used in this research were the secondary data, the unit of analysis and observation taken from two job sites online that jobstreet.co.id and karir.com in 2016. The sampling technique used was incidental sampling technique totaling 385 sales jobs. The analysis technique was using content analysis. The results showed that the all five dimensions of competence that has been elaborated by Palan (2007) with some of the indicators used for observations of job competencies of sales obtained results that all the indicators requested by the company and after gathering more data turns out there is also an additional tool such as supporting jobs, GPA, residency and physical health.
\end{abstract}

Keywords: E-recruitment, Jobs Advertisement, OnlineMedia, Competence

\begin{abstract}
Abstrak
Rendahnya minat para pencari kerja untuk mengisi posisi pekerjaan di bidang sales diduga karena tingginya kriteria kompetensi yang ditetapkan perusahaan untuk lowongan kerja sales. Dengan adanya dugaan tersebut peneliti tertarik untuk menganalisis kompetensi yang dibutuhkan perusahaan untuk calon karyawan di bidang sales, yang dipublikasikan pada situs lowongan pekerjaan di media online. Dengan adanya penelitian ini diharapkan dapat memberikan manfaat bagi para pencari kerja dengan tujuan untuk mengeksplorasi kompetensi-kompetensi yang dibutuhkan perusahaan pada bagian sales. Data yang digunakan menggunakan data sekunder, dengan unit analisis dan pengamatan yang diambil dari dua situs lowongan pekerjaan online yaitu jobstreet.co.id dan karir.com pada tahun 2016. Teknik pengambilan sampel menggunakan teknik incidental sampling yang berjumlah 385 lowongan pekerjaan sales. Teknik analisis data menggunakan content analysis. Hasil penelitian menunjukkan bahwa dari lima dimensi kompetensi yang telah dijabarkan oleh Palan (2007) dengan beberapa indikator yang digunakan untuk pengamatan kompetensi lowongan pekerjaan salesdidapatkan hasil bahwa semua indikator tersebut diminta oleh perusahaan dan setelah mengumpulkan lebih banyak data ternyata ada juga tambahan seperti alat penunjang pekerjaan, IPK, domisili dan kesehatan fisik didalamnya.
\end{abstract}

Kata Kunci: E-recruitment, Lowongan Pekerjaan, Online Media, Kompetensi 


\section{Pendahuluan}

Keberhasilan perusahaan tidak hanya berasal dari tenaga SDMnya saja, melainkan dalam diri SDM juga perlu adanya fondasi yang kuat untuk menghadapi persainganpersaingan bisnis yang semakin ketat seperti ini. Guna mencapai keberhasilan tersebut, karyawan atau sumber daya manusia di dalam perusahaan harus memiliki kompetensi. Dimana kompetensi menurut Marwansyah (2012) adalah perpaduan pengetahuan, keterampilan, sikap, dan karakteristik pribadi lainnya yang diperlukan guna mencapai keberhasilan dalam sebuah pekerjaan, yang dapat diukur dengan standar yang telah disepakati dan dapat ditingkatkan melalui pelatihan dan pengembangan.Kemudian Kessler (2011) juga telah menyimpulkan bahwasanya kompetensi merupakan karakteristik yang dimiliki karyawan terbaik untuk membantu mereka menjadi berhasil. Karakteristik yang dimaksudkan disini adalah list yang didalamnya terdapat sub-sub atau beberapa jenis karakteristik yang terdiri dari jenis yang berbeda, yang dapat mendorong perilaku pekerja dengan harapan dapat terciptanya kinerja yang unggul dan efektif. Selain itu juga diharapkan dapat memberikan hasil kinerja yang sesuai dengan tujuan yang sudah ditetapkan perusahaan. Oleh karena itu bisa diartikan bahwa kompetensi merupakan karakteristik yang mendasari cara seseorang berperilaku ditempat kerja. Seperti yang telah didefinisikan oleh Palan (2007) bahwasanya kompetensi adalah mengenai orang seperti apa dan apa yang dapat mereka lakukan, bukan apa yang mungkin mereka lakukan.

Berdasarkan penjelasan yang telah dijelaskan sebelumnya dapat disimpulkan bahwa kesuksesan perusahaan tidak akanberjalan mulus sesuai rencana, jika karyawan dalam perusahaan tidak memiliki kompetensi. Berbicara masalah karyawan dan kompetensi, rekrutmen adalah strategi yang bagus untuk mendapatkan karyawan yang berkompeten, karena rekrutmen SDM (Human Resource Recruitment) menurut Noe et al (2013) merupakanpraktik atau aktivasi yang dijalankan oleh organisasi dengan tujuan utamanya untuk mengidentifikasi dan menarik para karyawan potensial. Metode rekrutmen saat ini tidak hanya monoton menggunakan metode tradisional seperti tempo dulu. Seiring dengan berjalannya waktu dan perkembangan zaman yang semakin canggih ini, banyak perusahaan-perusahaan yang mulai memanfaatkan internet untuk media pencarian calon karyawan baru (e-recruitment).

Recruitment melalui internet menurut Marwansyah (2012) adalah penggunaan sistem online untuk merekrut calon karyawan. Mengingat semakin banyaknya perusahaan yang menggunakan media online untuk pencarian karyawan baru, dapat disimpulkan bahwa metode rekrutmen secara online adalah metode yang relatif lebih mudah di akses, relatif murah dan yang pasti cost-effective untuk menarik pelamar yang berkompetensi.

E-recruitment atau mencari kerja menggunakan media online memang praktis dan mudah diakses. Bisa dibuktikan dengan adanya teknologi komputer dan internet yang memberikan banyak kemudahan dalam dunia bisnis. E-recruitment merupakan model mencari kerja menggunakan media online yang saat ini menjadi win-win solution baik bagi perusahaan ataupun dari sisi pencari kerja. Berbicara masalah E-recruitment, lowongan kerja sales juga banyak ditemukan di berbagai situs lowongan kerja online. Karena seperti yang telah kita ketahui bahwa pekerjaan sales merupakan pekerjaan yang memiliki bonus gaji lumayan besar. Jika dilihat dari besarnya bonus yang nantinya akan diperoleh seharusnya lowongan kerja sales adalah pilihan pekerjaan yang banyak diminati oleh para pencari kerja. Namun berdasarkan hasil wawancara peneliti yang didapat dari kedua narasumber yang berbeda yaitu narasumber pertama merupakan BM Bank Swasta di Salatiga dan narasumber kedua adalah Produsen Baterai dan Accuternama di Jakarta, menyatakan bahwa peminat untuk para pencari kerja (jobseeker) pada posisi bagian sales peminatnya masih sangat kurang atau bisa dibilang tidak ada peminat untuk 
posisi lowongan pekerjaan ini. Yang diduga karena tingginya kriteria kompetensi yang telah ditetapkan perusahaan untuk lowongan kerja sales atau pencari kerja tidak memiliki kompetensi yang cukup untuk mengisi posisi tersebut.

Dilihat dari rendahnya minat pada lowongan kerja sales yang diduga karena tingginya kriteria yang diminta perusahaan. Dapat ditarik kesimpulan bahwa rendahnya minat tersebut diakibatkan karena ketidak cocokan antara kompetensi yang dimiliki para jobseeker dengan kriteria kompetensi yang telah ditetapkan perusahaan.Kompetensi merujuk kepada karakteristik yang mendasari perilaku yang menggambarkan motif, karakteristik pribadi (ciri khas), konsep diri, nilai-nilai, pengetahuan atau keahlian yang dibawa seseorang yang berkinerja unggul (superior performer) di tempat kerja (Palan, 2007). Dari pernyataan tersebut dapat ditunjukkan bahwa dalam suatu bisnis penggunaan kompetensi menjadi penting. Dengan mengetahui karakteristik yang dapat membuat karyawan berkinerja unggul, maka perusahaan dapat membuat keputusan yang lebih baik pada saat mempekerjakan dan menempatkan karyawan. Berangkat dari permasalahan tersebut dapat disimpulkan bahwa kompetensi merupakan masalah utama dalam permasalahan ini. Oleh sebab itu peneliti tertarik untuk menganalisis kompetensi yang dibutuhkan perusahaan untuk calon karyawan bagian sales yang dipublikasikan pada situs lowongan pekerjaan di media online. Dengan adanya penelitian ini diharapkan dapat memberikan manfaat bagi para jobseeker guna mengetahui kriteria kompetensi apa saja yang tengah diharapkan oleh perusahaan untuk calon karyawan pada bagian sales. Berdasarkan rumusan masalah yang telah teridentifikasi, peneliti menarik persoalan penelitian yaitu "Apa saja kompetensi yang diharapkan perusahaan untuk karyawan bagian sales?". Jadi tujuan penelitian ini adalah untuk mengeksplorasi kompetensi-kompetensi yang dibutuhkan perusahaan untuk bagian sales.

\section{Tinjauan Pustaka}

\section{Kompetensi}

Kompetensiadalah acuan bagi para manajemen perusahaan dalam mengelola human capital yang secara efektif menerjemahkan visi serta tujuan-tujuan strategis organisasi kedalam perilaku yang teramati atau tindakan-tindakan yang harus dikerjakan oleh para karyawan, mulai dari proses rekrutmen dan seleksi, manajemen kinerja, pelatihan dan pengembangan, manajemen karyawan potensial, hingga retensi dan remunerasi (Marwansyah, 2012).

Palan (2007) mendefinisikan bahwa kompetensi adalah karakter dasar orang yang mengidentifikasikan cara berperilaku atau berpikir, yang berlaku dalam cakupan situasi yang sangat luas dan bertahan untuk waktu yang lama.

Kompetensi terbagi menjadi lima dimensi.

a. Pengetahuan adalah pengetahuan yang merujuk pada informasi dan hasil pembelajaran. Seperti pengetahuan karyawan turut menentukan berhasil tidaknya pelaksanaan tugas yang dibebankan kepadanya, karyawan yang mempunyai pengetahuan yang cukup akan meningkatkan efisiensi perusahaan. Namun begitu juga sebaliknyabagikaryawanyangbelum mempunyai pengetahuan cukup, maka akan bekerja tersendat-sendat. Seperti halnya: pemborosan bahan, waktu, tenaga dan faktor produksi lainnya yang akan diperbuat oleh karyawan berpengetahuan kurang. Pemborosan ini akan mempertinggi biaya dalam pencapaian tujuan organisasi.

b. Keterampilan adalah keahlian merujuk pada kemampuan seseorang untuk melakukan suatu kegiatan. Seperti halnyakaryawan yang mempunyai kemampuan kerja yang baik, maka akan mempercepat pencapaian tujuan organisasi, 
sebaliknya karyawan yang tidak terampil akan memperlambat tujuan organisasi. Bagi karyawan yang masih baru atau karyawan dengan tugas baru diperlukan tambahan kemampuan untuk mengerjakan tugas-tugas yang dibebankan kepadanya.

c. Konsep diri dan nilai-nilai adalah konsep diri dan nilai-nilai yang merujuk pada sikap, nilainilai serta citra diri seseorang. Disamping pengetahuan dan keterampilan karyawan, hal yang perlu diperhatikan adalah sikap atau perilaku kerja karyawan. Apabila pegawai memiliki sifat yang mendukung tercapainya tujuan organisasi, maka secara otomatis segala tugas yang telah dibebankan kepadanya akan dilaksanakan dengan sebaik-baiknya.

d. Karakteristik pribadi adalah karakteristik pribadi yang merujuk pada karakteristik fisik beserta konsistensi tanggapan terhadap situasi atau informasi. Karakteristik pribadi yang dimaksud merupakan cerminan bagaimana seorang karyawan mampu atau tidak dalam melakukan aktivitas dan tugas secara mudah atau sulit dan sukses atau tidak pernah sukses.

e. Motifadalahemosi,hasrat,kebutuhan psikologis, atau dorongan-dorongan lain yang memicu tindakan. Selain itu motif juga merupakan kekuatan pendorong yang akan menjadikan suatu perilaku untuk mencapai tujuan kepuasan dirinya.

\section{Rekrutmen}

Rekrutmen adalah proses untuk mendapatkan calon karyawan yang memiliki kemampuan sesuai dengan kualifikasi dan kebutuhan suatu organisasi atau perusahaan (Mardianto, 2014). Menurut Mardianto
(2014) tujuan dari aktifitas rekrutmen itu sendiri adalah:

a. Menjamin perusahaan memilki karyawan yang tepat untuk suatu jabatan atau pekerjaan.

b. Mengevaluasi dalam mempekerjakan dan penempatan pelamar sesuai minat.

c. Memperlakukan pelamar secara adil dan meminimalkan diskriminasi.

d. Memperkecil munculnya tindakan buruk karyawan yang seharusnya tidak diterima.

e. Memastikan keuntungan dari investasi sumber daya manusia.

Rekrutmen merupakan usaha untuk mengisi jabatan atau pekerjaan yang kosong di lingkungan organisasi atau perusahaan (Nawawi, 2003). Sedangkan menurut Marwansyah (2012) rekrutmen adalah upaya menemukan calon kayawan yang memiliki kemampuan dan sikap yang dibutuhkan oleh organisasi dan mencocokannya dengan tugas-tugas yang harus dijalankan. Sumber rekrutmen dapat digolongkan kedalam dua jenis, yakni: sumber internal dan sumber eksternal. Sumber internal dalam rekrutmen meliputi karyawanyang ada sekarang yang dapat dicalonkan untuk dipromosikan, dipindah tugaskan atau dirotasi tugasnya, serta mantan karyawan yang bisa dikaryakan dan dipanggil kembali. Sedangkan sumber eksternal merupakan sumber untuk mendapatkan karyawan dari luar perusahaan yang memiliki bobot atau kualifikasi tertentu. Sumber yang dapat dilakukan adalah dengan program referral karyawan.

Selain metode-metode 'tradisional' yang sering digunakan, kini telah muncul perkembangan teknologi informasi yang lebih praktis dan mudah digunakan perusahaan untuk mencari calon karyawan yaitu dengan memanfaatkan internet. Diantaranya adalah iklan, rekrutmen melalui internet, agen tenaga kerja, perusahaan pencari eksekutif, rekrutmen melalui acara khusus, rekrutmen 
diperguruan tinggi, pemagangan, asosiasi profesi, referensi karyawan dan lamaran tak diterima.

Rekrutmen berlangsung sebagai proses penyesuaian antara karakteristik pekerjaan yang dikehendaki organisasi atau perusahaan dengan usaha seorang calon pekerja dalam mencari pekerjaan. Dengan demikian kedua belah pihak antara perusahaan dengan calon pekerja akan terjadi pertemuan (titik temu) dari dua arah. Rekrutmen dua arah menurut Nawawi (2003) adalah proses yang mampu memberikan kepuasan kepada pihak perusahaan dan pencari kerja. Dengan begitu dapat dikatakan bahwa peranan media komunikasi penting dalam proses pelaksanaan rekrutmen karena dapat menyebar luaskan maksud dari perusahaan, melalui advertensi tentang tenaga kerja yang dibutuhkan perusahaan. Sedangkan dari calon pekerja sendiri juga mendapat kemudahan dari proses rekrutmen ini karena dengan membaca advertensi di media online dapat digunakan untuk mencocokkan karakteristik pekerjaan yang dikehendaki perusahaan dengan kondisi atau keadaan diri calon pekerja untuk melamar pekerjaan tersebut.

\section{Online Recruitment}

Online Recruitment atau E-recruitment menurut In Lee dalam buku Marwansyah (2012) mendefinisikan sebagai praktik dan aktivasi yang dilakukan oleh organisasi dengan mendayagunakan beragam sarana elektronik untuk mengisi jabatan atau posisi yang lowong secara efektif dan efisien. Kemudian didefinisikan juga oleh Purnomo (2013) bahwa e-recruitment merupakan suatu manifestasi dari kemajuan teknologi yang telah membawa manfaat besar bagi perekrutan perusahaan serta implementasi yang ideal dapat dijalankan dengan sukses oleh semua jenis perusahaan lebih dari asumsi bahwa perusahaan akan mendapatkan manfaat dari sistem tersebut.

Noe et al. (2013) juga mengemukakan bahwa bidang manajemen SDM yang dinamis ini merupakan salah satu bidang yang inovatif, dimana para manajer yang berpikiran maju dapat mencapai keunggulan bersaing yakni "Bersaing Melalui Teknologi" yang telah berkembang dan telah berubah menjadi sarana rekrutmen.

Keunggulan Online Rekruitmen menurut Noe et al. (2013):

a. Media ini memungkinan para pencari kerja untuk mengisi surveisurvei yang menguraikan halhal yang mereka cari dan hal-hal yang harus mereka tawarkan pada perusahaan.

b. Perekrut dari pihak perusahaan juga lebih cepat dalam menilai dan memberikan umpan balik langsung tentang seberapa cakapnya mereka menyesuaikan diri pada perusahaan.

c. Para pelamar juga dapat mencari perusahaan-perusahaan yang sama, dengan harapan mungkin ada kesesuaian di antara pengusaha dengan pelamar.

d. Memperpendek siklus waktu perekrutan.

\section{Metode Penelitian}

\section{Jenis Penelitian}

Jenis penelitian yang digunakan dalam penelitian ini adalah penelitian kualitatif dimana penelitian kualitatif menurut Sarwono (2006) merupakan pengumpulan data yang bersifat deskriptif, data yang dimaksudkan berupa gejala-gejala yang di kategorikan ataupun dalam bentuk lainnya seperti: foto, dokumen, artifak dan catatan-catatan lapangan saat penelitian dilaksanakan. Dalam penelitian ini data yang dimaksud adalah dokumen.

\section{Metode Pengumpulan Data}

Metode pengumpulan data dalam penelitian ini menggunakan sumber data sekunder. Seperti yang telah dijelaskan Sugiyono (2012) bahwa data sekunder merupakan sumber yang tidak langsung memberikan data kepada pengumpul data, misalnya lewat orang lain atau lewat dokumen. Data sekunder yang dimaksudkan disini 
adalah data sekunder dari iklan lowongan kerja online.

\section{Unit Analisis dan Pengamatan}

Dalam penelitian ini unit analisis diambil dari iklan lowongan pekerjaan online. Lowongan pekerjaan tersebut dibatasi hanya di bidang sales. Adapun situs lowongan kerja yang digunakan untuk unit analisis adalah situs yang berbahasa Indonesia dan menyediakan lowongan kerja di Indonesia dalam kurun waktu tahun 2016. Situs yang dimaksud disini yaitu jobstreet.co.id dan karir.com dengan teknik pengambilan sampel yaitu sampel non probability dengan incidentalsampling. Incidental sampling adalah teknik penentuan sampel berdasarkan kebetulan, yang mana secara tidak sengaja data ditemukan dan dapat digunakan sebagai sampel (Sugiyono, 2013). Total data yang digunakan berjumlah 385 lowongan pekerjaan yang berbeda, karena menurut Thompson (2012) jumlah sampel untuk data yang tidak diketahui populasinya adalah sebesar 385 .

\section{Teknik Analisis Data}

Teknik analisis data yang digunakan adalah content analysis yang dimana menurut Bulaeng (2004) merupakan suatu tahap dari pemrosesan informasi yang menyangkut isi-isi komunikasi yang ditransformasikan melalui aplikasi yang sistematik dan objektif menurut ketentuan kategorisasi ke dalam data yang dapat diinterpretasi dan dibandingkan.

\section{Hasil Dan Pembahasan}

Berikut ini akan dijabarkan hasil beserta pembahasan secara ringkas mengenai apa saja kompetensi yang dibutuhkan perusahaan untuk karyawan bagian sales. Dengan tujuan untuk mengeksplorasi kompetensikompetensi yang dibutuhkan perusahaan untuk sales pada kurun waktu tahun 2016.

\section{Karakteristik Sampel}

Pada penelitian ini peneliti mengambil beberapa sampel lowongan pekerjaan sales yang ada di media online sebagai bahan penelitian, yang mana peneliti mengumpulkan beberapa sampel lowongan kerja sales tersebut dari beberapa lowongan kerja yang telah peneliti dapatkan. Peneliti memilah-milah satu per satu kualifikasi yang telah ditetapkan di dalamnya dan kemudian dipetakan ke dalam beberapa dimensi-dimensi kompetensi. Data diambil dari dua situs lowongan kerja online yang berbeda yang banyak diminati oleh masyarakat yaitu jobstreet.co.id dan karir.com pada kurun waktu tahun 2016. Dengan jumlah lowongan pekerjaan sebanyak 385 lowongan pekerjaan yang terdiri dari 366 perusahaan yang berbeda. Dari 385 lowongan pekerjaan tersebut terdapat beberapa tingkat kategori lowongan pekerjaan sales, diantaranya yaitu: sales atau marketing, sales atau marketing manager dan supervisor sales atau marketing. Pada tingkat kategori sales atau marketing memiliki hasil persentase yang paling tinggi yaitu sebesar 85 persen, kemudian sales atau marketing manager sebesar 8 persen dan untuk supervisor sales atau marketing sebesar 7 persen.

\section{Hasil Penelitian}

Penelitian ini membahas mengenai isi suatu informasi pada kualifikasi lowongan kerja sales yang didapat dari kedua situs lowongan pekerjaan di media online. Peneliti melihat dari sisi kompetensi, yang mana kompetensi merupakan seperangkat tindakan yang dimiliki seseorang sebagai syarat untuk dianggap cakap dalam melaksanakan tugastugas pada bidang pekerjaan tersebut. Seperti yang telah dipaparkan oleh Palan (2007) bahwa kompetensi merupakan karakteristik dasar orang yang mengidentifikasi cara berperilaku atau berfikir, yang berlaku dalam cakupan situasi yang sangat luas dan bertahan untuk waktu yang lama. Dalam penelitian ini, peneliti membagi hasil penelitian menjadi lima sub-sub bab, diantaranya yaitu:

a. Pengetahuan adalah pengetahuan yang merujuk pada informasi dan hasil pembelajaran. 
b. Keterampilan adalah keahlian merujuk pada kemampuan seseorang untuk melakukan suatu kegiatan.

c. Konsep diri dan nilai-nilai adalah konsep diri dan nilai-nilai yang merujuk pada suatu sikap serta nilainilai dan citra diri seseorang.

d. Karakteristik pribadi adalah karakteristik pribadi yang merujuk pada karakteristik fisik serta konsistensi tanggapan terhadap situasi atau informasi.

e. Motif adalah emosi, hasrat, kebutuhan psikologis, atau dorongan-dorongan lain yang memicu tindakan.

\section{Pengetahuan}

Pengetahuan seorang karyawan sangat menentukan berhasil atau tidaknya pelaksanaan tugas yang telah dibebankan kepadanya, karyawan yang mempunyai pengetahuan yang cukup akan meningkatkan efisiensi perusahaan dan juga sebaliknya karyawan yang kurang memiliki pengetahuan akan memperlambat pelaksanaan tugas yang dibebankan. Berdasarkan penelitian yang dilakukan, peneliti membagi pengetahuan menjadi dua kategori yaitu: pendidikan dan pengalaman, namun setelah mengumpulkan lebih banyak data peneliti memperoleh satu kategori yang dirasa cocok untuk masuk dalam dimensi pengetahuan yaitu IPK (Indeks Prestasi Kumulatif).

Bisa dilihat pada Gambar 1 kategori pendidikan telah menunjukkan bahwa lulusan SMA memiliki hasil persentase sebesar 34 persen, lulusan D1 sebesar 2 persen, lulusan D3 sebesar 36 persen, lulusan S1 sebesar 18 persen dan yang tidak mencantumkan ada sebesar 10 persen. Dengan hasil yang demikian bisa dikatakan bahwa kualifikasi yang banyak dibutuhkan perusahaan untuk karyawan sales adalah calon karyawan yang berpendidikan D3 atau SMA sederajat.

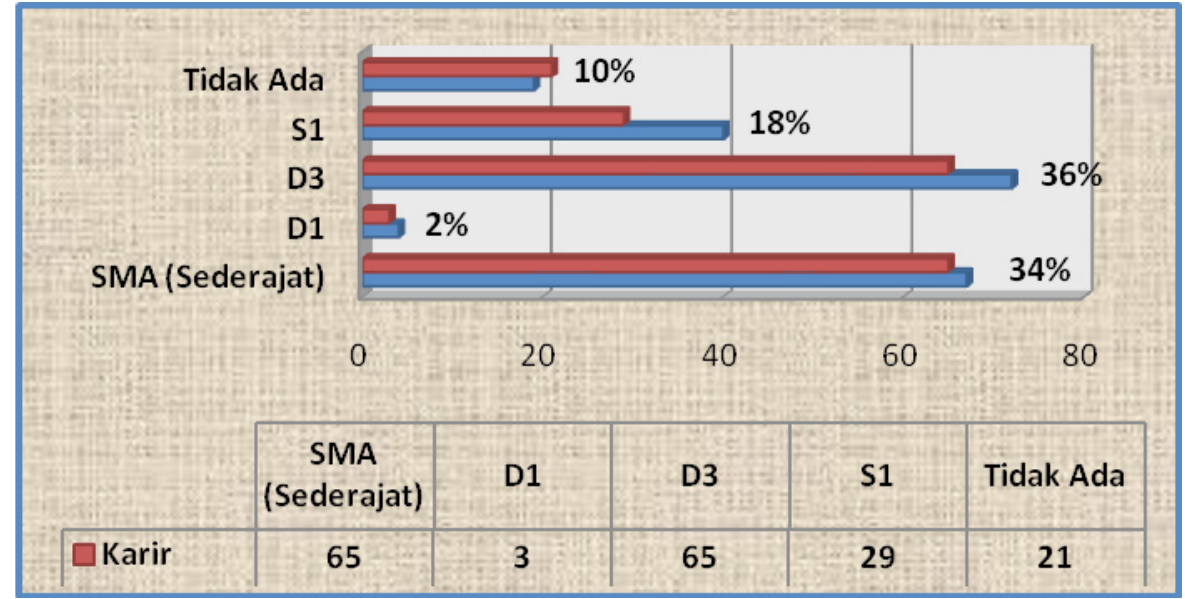

Gambar 1. Latar Belakang Pendidikan

Sumber: Data diolah, 2016

Salah satu data yang jugadikategorikan dalam pengetahuan adalah pengalaman. Yang dimana pengalaman merupakan salah satu pijakan untuk meraih kata "profesional". Karena dalam sebuah organisasi dan juga perusahaan, pengalaman sangat berpengaruh terhadap peningkatan karir. Begitu juga dengan perusahaan yang mencari karyawan untuk di tempatkan pada posisi sales, pasti perusahaan menginginkan calon karyawan yang berpengalaman dalam bidang sales. Oleh sebab itu peneliti mengambil kategori pengalaman dalam dimensi pengetahuan sebagai bahan analisis. Dari hasil penelitian yang telah dilakukan, peneliti menyimpulkan bahwasanya pengalaman yang dikehendaki oleh satu perusahaan dengan perusahaan lainnya sangat bervarian. Ada beberapa kategori pengalaman kerja yang harus dimiliki calon karyawan sales, bisa dilihat bahwa 
pengalaman kerja yang banyak dibutuhkan oleh perusahaan adalah mereka para calon pelamar kerja yang telah memiliki pengalaman dibidang sales marketing minimal 1 sampai 3 tahun dengan jumlah persentase sebesar 44 persen dan untuk jumlah persentase terbesar kedua yaitu untuk pengalaman kerja sales marketing tanpa diperhitungkan lama kerjanya dengan jumlah persentase 24 persen.

IPK memang bukan segalanya tapi seperti yang telah kita lihat bahwa IPK merupakan gerbang untuk kita menuju satu tahapan sukses yaitu masuk dalam dunia kerja. Itu sebabnya setelah mengumpulkan lebih banyak data peneliti memasukkan kategori IPK dalam dimensi pengetahuan. Bisa dilihat pada gambar 3 telah disebutkan bahwa standar IPK 2.75 memiliki hasil persentase sebesar 1 persen, IPK 3.00 sebesar 2 persen dan ada sebesar 97 persen perusahaan yang tidak mencantumkan IPK, kemudian untuk IPK 2.8 dan 2.5 memiliki persentase sebesar 0 persen.

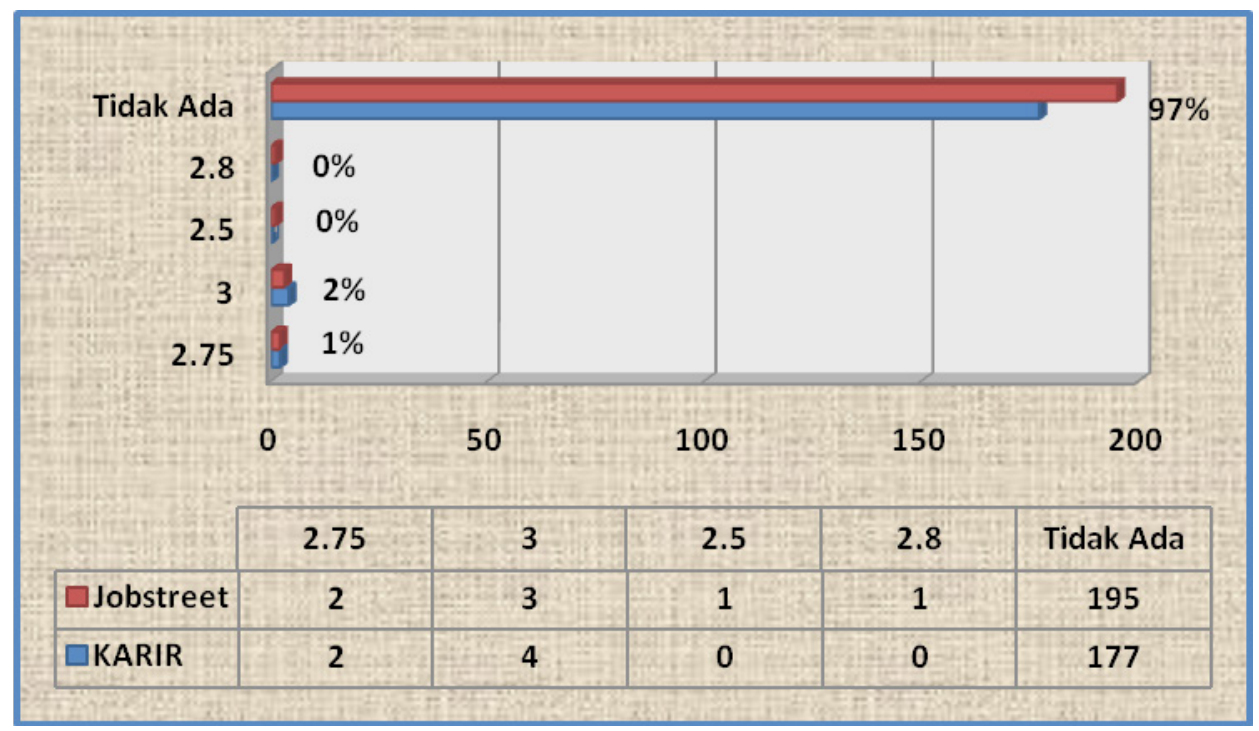

Gambar 2. Standar IPK

Sumber: Data diolah, 2016

\section{Keterampilan}

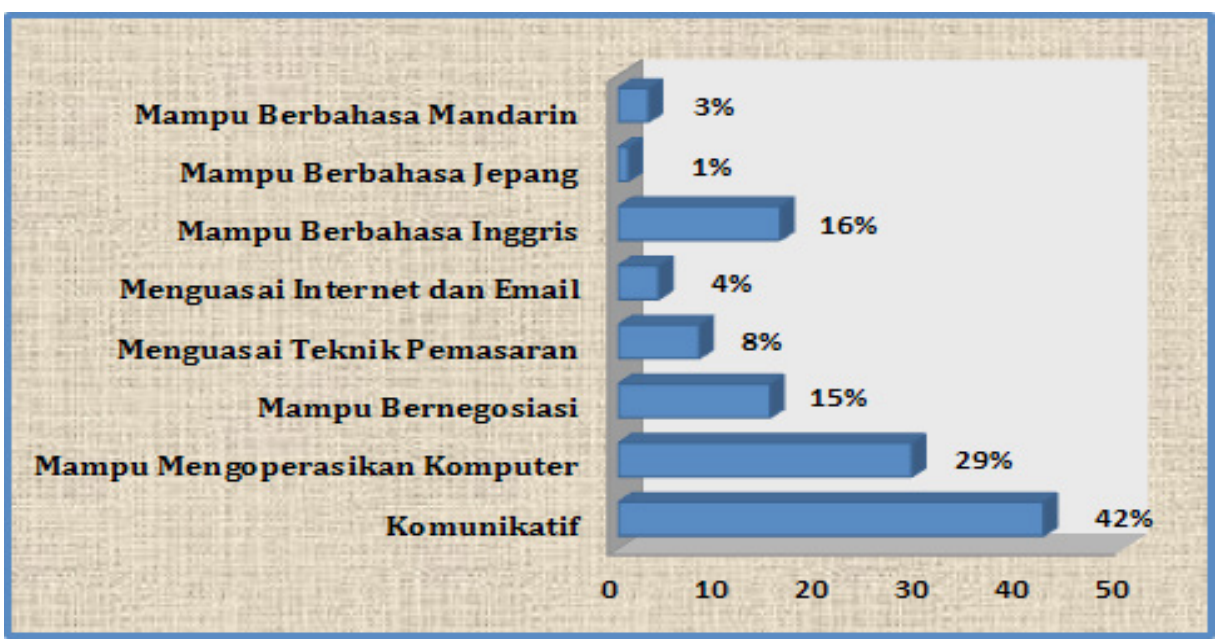

Gambar 3. Kemampuan

Sumber: Data diolah, 2016 
Keterampilan karyawan dalam bekerja akan mempercepat pencapaian tujuan organisasi dan juga sebaliknya karyawan yang tidak trampil akan memperlambat tujuan organisasi. Bisa dilihat pada gambar 4 peneliti telah mengkategorikan dimensi keterampilan kedalam dua kategori didalamnya, yaitu: kemampuan dan kreatif. Hasil penelitian menunjukkan bahwa jumlah persentase untuk kemampuan berbahasa mandarin 3 persen, mampu berbahasa jepang 1 persen, menguasai internet dan email 4 persen, menguasai teknik pemasaran 8 persen, mampu berbahasa inggris 16 persen, mampu bernegosiasi 15 persen, mampu menguasai operasional komputer 29 persen, komunikatif 42 persen. Dengan melihat hasil persentasi yang telah disebutkan, peneliti menyimpulkan bahwa kemampuan yang banyak dibutuhkan oleh perusahaan adalah para calon karyawan yang komunikatif dan didukung dengan mampu mengoperasikan komputer.

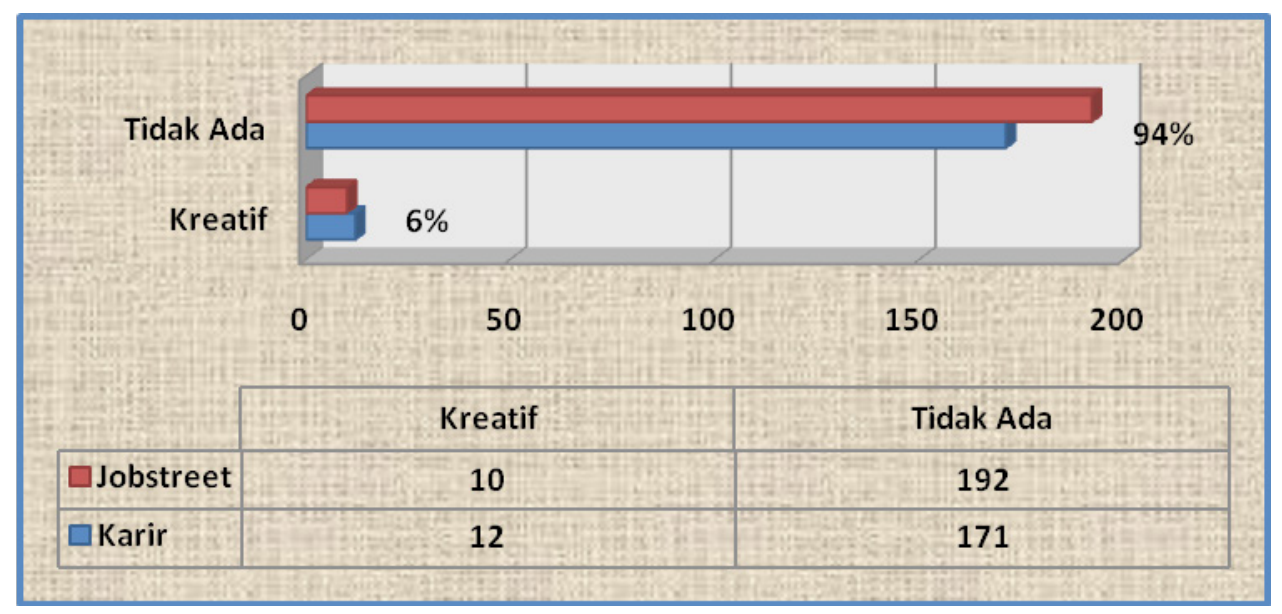

Gambar 4. Kreatif

Sumber: Data diolah, 2016

Kemudian salah satu data yang jugadikategorikan dalam keterampilan adalah kreatif, Dimana kreatif akan menjadikan karyawan menemukan hal atau hubunganhubungan baru dan menemukan solusisolusi yang imajinatif untuk memperoleh kata sukses dalam setiap pekerjaannya. Oleh karena itu peneliti memasukkan indikator kreatif kedalam dimensi keterampilan. Setelah melakukan penelitian yang lebih mendalam didapatkan hasil bahwa perusahaan yang mencantumkan kreatif sebagai kualifikasi didalamnya hanya memiliki hasil persentase sebesar 6 persen yang bisa dilihat pada gambar 4.

\section{Konsep Diri dan Nilai-nilai}

Disamping pengetahuan dan ketrampilan karyawan, hal yang perlu diperhatikan juga adalah sikap atau perilaku kerja karyawan. Karena apabila karyawan dalam perusahaan mempunyai sifat yang mendukung pencapaian tujuan organisasi, maka secara otomatis segala tugas yang dibebankan kepadanya akan dilaksanakan dengan sebaik-baiknya. Dalam dimensi konsep diri dan nilai-nilai peneliti telah memasukkan beberapa kategori didalamnya, namun setelah mengumpulkan lebih banyak data, peneliti memperoleh lebih banyak lagi konsep diri dan nilai-nilai yang banyak dicantumkan sebagai kualifikasi atau standar calon pekerja yang dibutuhkan perusahaan, antaralain: jujur, rajin, dapat bekerjasama, etos kerja tinggi, sabar, aktif, berpikir kritis, cepat beradaptasi, dan lainlain. Untuk hasil konsep diri dan nilai-nilai menunjukkan bahwa yang paling banyak ditemukan peneliti adalah jujur dengan jumlah persentase sebesar 24 persen.

\section{Karakteristik Pribadi}

Karakteristik pribadi dalam perusahaan merupakan cerminan bagaimana seseorang karyawan mampu atau tidak dalam melakukan 
suatu aktivitas dan tugas secara mudah atau sulit. Oleh sebab itu karakteristik pribadi merupakan hal penting yang harus diketahui oleh pemimpin atau kepala perusahaan guna mempermudah kinerja dalam perusahaan. Pada dimensi karakteristik pribadipeneliti membagi dalam lima kategori yang ada didalamnya, yaitu: jenis kelamin, usia, penampilan, memiliki alat penunjang pekerjaan dan status. Setelah dilakukan pengumpulan data yang lebih banyak peneliti menemukan dua kategori yang menurut peneliti masuk dalam indikator karakteristik pribadidiantaranya ada tempat tinggal (domisili) dan kesehatan fisik.

Pada kategori jenis kelamin mendapatkan hasil bahwa jumlah persentase untuk jenis kelamin wanita sebesar 4 persen, pria sebesar 5 persen, pria atau wanita sebesar 11 persen sedangkan untuk perusahaan yang tidak mencantumkan sebesar 79 persen.

Dari hasil penelitian yang telah dilakukan untuk kualifikasi usia bisa dilihat pada gambar 7 bahwa untuk umur maksimal 20 sampai 25 tahun sebesar 5 persen, 26 sampai 30 tahun 26 persen, 31 sampai 35 tahun 30 persen, 36 sampai 40 tahun 6 persen, 41 sampai 50 tahun 2 persen dan yang tidak mencantumkan ada sebanyak 31 persen. Dari hasil yang telah didapatkan bisa dilihat bahwa untuk jumlah persentase tertinggi adalah untuk maksimal umur 31 sampai 35 tahun dengan jumlah persentase terbesar yaitu 30 persen. Dari hasil tersebut bisa diambil kesimpulan bahwa maksimal umur yang dibutuhkan perusahaan adalah kisaran umur 35 kebawah.

Bisa dikatakan bahwa penampilan merupakan background diri seseorang, karena sebelum orang lain mengerti akan sifat dan kemampuan yang kita miliki orang lain akan lebih dulu menilai penampilan kita. Selain meningkatkan percaya diri berpenampilan juga menggambarkan seberapa jauh profesionalisme seseorang. Dari hasil penelitian pada gambar 8 telah membuktikan bahwa menarik menempati jumlah persentase paling besar yaitu 27 persen, proporsional 2 persen, tinggi 2 persen, rapi 1 persen dan ada juga perusahaan yang tidak mencantumkan sebesar 68 persen.

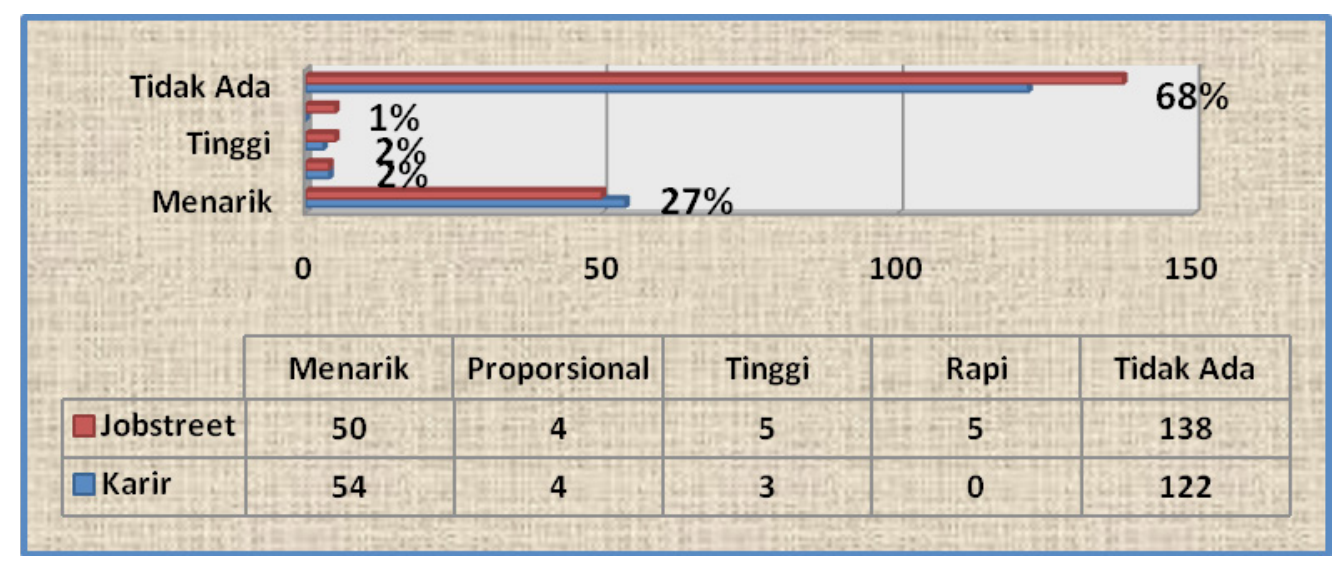

Gambar 5. Penampilan

Sumber: Data diolah, 2016

Selain penampilan, calon karyawan sales juga harus memiliki alat penunjang pekerjaan. Dengan adanya alat penunjang pekerjaan aktifitas dalam bekerja akan berjalan dengan lancar. Seperti halnya sales yang selalu berkecimpung dengan masyarakat luas tentu alat penunjang sangat penting sekali. Dari penelitian yang telah dilakukan didapatkan hasil bahwa alat penunjang yang dibutuhkan untuk perusahaan bagi para calon karyawan sales bisa dilihat pada gambar 9 dengan hasil untuk alat penunjang pekerjaan berupa SIM A sebesar 4 persen, SIM C sebesar 13 persen, SIM A atau C sebesar 10 persen, motor pribadi sebesar 26 persen, memiliki kendaraan roda dua atau empat sebesar 1 persen, memiliki handphone 0 persen dan ada juga perusahaan yang tidak mencantumkan sebesar 47 persen. 
Dari hasil persentase yang telah didapatkan dapat ditarik kesimpulan bahwa alat penunjang yang dibutuhkan perusahaan untuk karyawan sales adalah motor pribadi dengan jumlah persentase sebesar 26 persen.

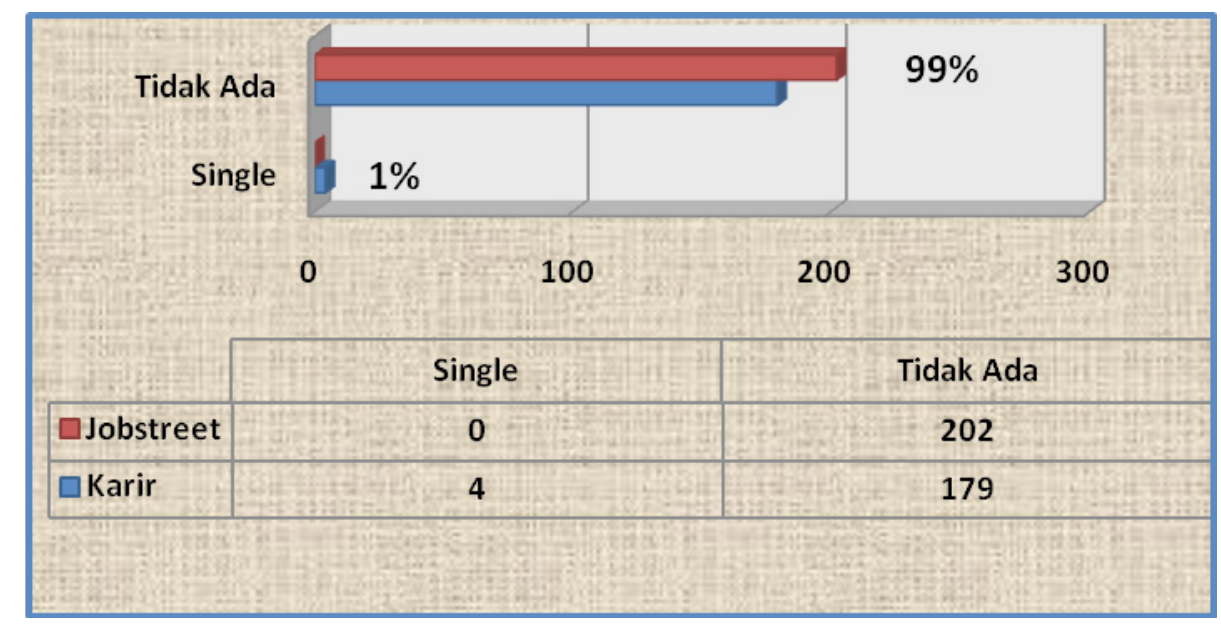

Gambar 6. Status

Sumber: Data diolah, 2016

Bisa dilihat juga pada gambar 6 telah menjelaskan bahwa pada lowongan kerja jobstreet.co.id sama sekali tidak menyinggung mengenai status seseorang calon pekerja. Tetapi berbeda dengan karir.com, setelah dilakukan penelitian ternyata ada empat perusahaan yang telah mencantumkan kualifikasi status didalamnnya. Dengan jumlah persentase sebesar 1 persen saja.

Untukwilayah tempattinggalataudomisili ada beberapa perusahaan yang mencantumkan sebagai kualifikasi didalamnya. Dari hasil penelitian untuk tempat tinggal (domisili) dari para calon pekerja bisa dilihat pada gambar 11, peneliti memisahkan domisili atau tempat tinggal sesuai dengan kepulauan. Berdasarkan penelitian yang telah dilakukan didapatkan hasil peneliti dengan jumlah persentase untuk pulau jawa sebesar 7 persen, Sulawesi sebesar 1 persen, Sumatra sebesar 0 persen, bali 0 persen, WNI 0 persen dan untuk perusahaan yang tidak mencantumkan domisili sebesar 92 persen.

Kesehatan merupakan nikmat utama yang dimiliki tiap individu, karena dengan tubuh yang sehat seluruh aktivitas serta pekerjaan akan berjalan dengan lancar dan apabila kesehatan terganggu maka akan mempengaruhi aktivitas serta pekerjaan. Dari hasil penelitian bisa dilihat pada Gambar 7 bahwa sehat jasmani dan rohani memiliki hasil persentase sebesar $2 \%$, tidak memiliki kelainan mata sebesar 0 persen dan yang tidak 


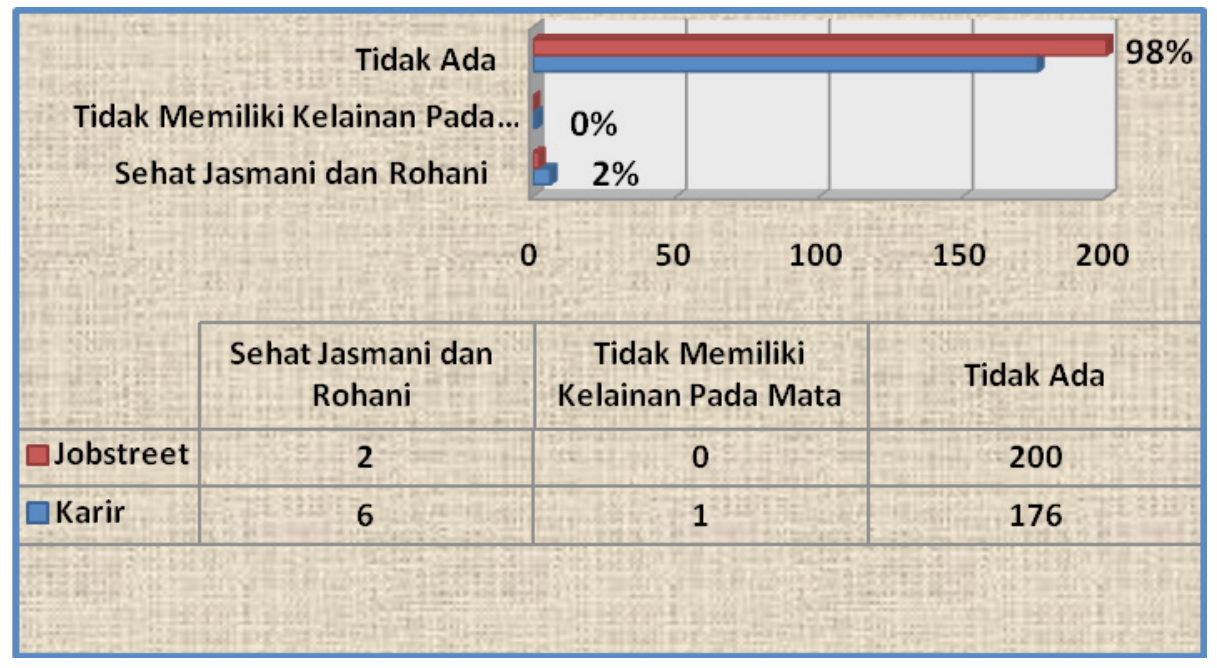

Gambar 7. Kesehatan Fisik

Sumber: Data diolah, 2016

\section{Motif}

Selain memicu untuk melakukan tindakan, motif juga merupakan kekuatan pendorong yang mewujudkan suatu perilaku guna mencapai tujuan kepuasan dirinya. Berdasarkan hasil penelitian telah menunjukkan bahwa menyukai tantangan memperoleh hasil sebesar 33, motivasi tinggi 13 persen, antusias 16 persen dan menyukai target ada sebesar 32 persen. Berdasarkan hasil yang telah disebutkan bisa diambil kesimpulan bahwa untuk calon pekerja sales harus memiliki motif atau menyukai yang namanya tantangan kerja.

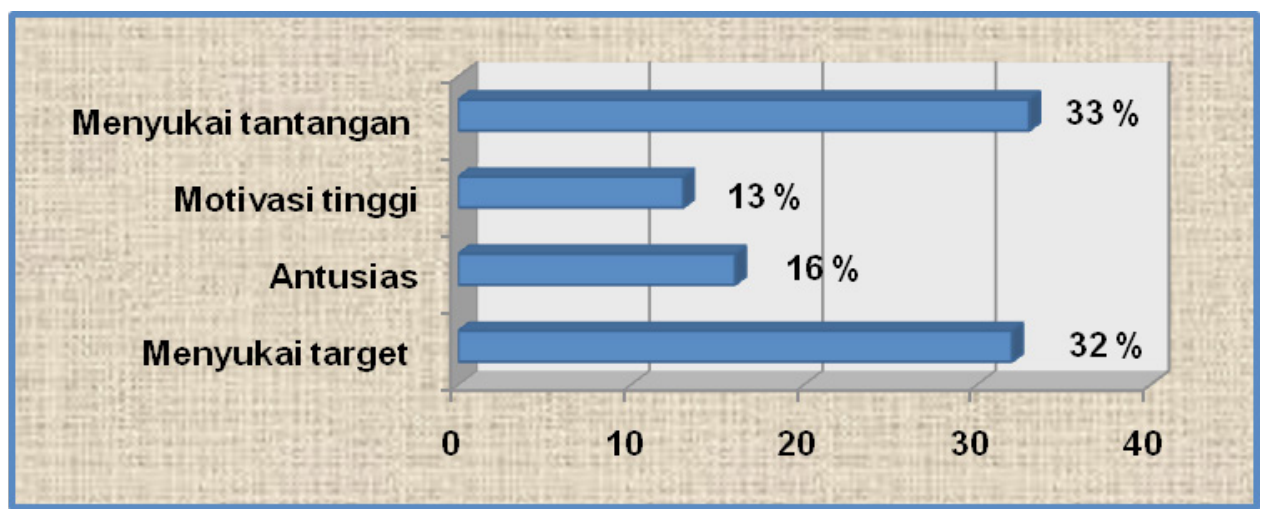

Gambar 8. Kategori Motif

Sumber: Data diolah, 2016

\section{Pembahasan}

Dari hasil penelitian yang telah dijelaskan sebelumnya, didapatkan hasil bahwa tingkat kategori yang paling banyak dicari oleh perusahaan adalah tingkat kategori sales atau marketing yang bukan supervisor atau manager. Jadi dari 385 lowongan kerja yang banyak dicari perusahaan adalah tenaga sales atau marketingnya saja bukan dilihat dari jabatan manajerialnya. Dari proses penelitian yang dilakukan, peneliti mengkategorikan indikator kompetensi menjadi 5 dimensi yaitu pengetahuan, keterampilan, konsep diri dan nilai-nilai, karakteristik pribadi serta motif. Pada dimensi pengetahuan didapatkan hasil bahwa untuk kriteria pendidikan yang banyak dicari oleh perusahaan adalah lulusan D3 dan strata SMA. Karena pendidikan merupakan tingkatan atau tolak ukur kemampuan calon pekerja untuk mendapatkan hasil yang efisien dalam pekerjaan dan sesuai dengan keinginan perusahaan. Seperti halnya yang telah dikatakan oleh Martono (2010) bahwa syarat pendidikan di sebagian besar 
lowongan pekerjaan yang diinformasikan di surat kabar adalah calon karyawan dengan tingkat pendidikan diploma dan tingkat pendidikan SMA atau sederajat. Sedangkan kriteria pengalaman kerja yang banyak dibutuhkan oleh perusahaan dalam penelitian ini adalah pengalaman minimal 1 sampai 3 tahun di bidang sales, karena dengan adanya pengalaman kerja seperti yang telah disebutkan diharapkan pengalaman tersebut mampu membuat calon karyawan mudah beradaptasi di tempat kerjanya yang baru, sehingga dapat memberikan kepuasan bagi perusahaan yang bersangkutan. Hal ini juga didukung oleh hasil penelitian Stefanie dan Indriyani (2014) yang mengatakan bahwa perusahaan tidak pernah merekrut calon karyawan yang 'fresh graduate"karena dinilai belum memiliki pengalaman dan syarat bekerja di perusahaan dan setelah mengumpulkan lebih banyak data peneliti menemukan ada beberapa perusahaan yang mencantumkan IPK sebagai kualifikasi di dalamnya namun masih banyak perusahaan yang tidak mencantumkan.

Dalam dimensi keterampilan didapatkan hasil bahwa yang banyak dibutuhkan dalam dunia kerja sales yaitu karyawan yang komunikatif dan mampu mengoprasikan komputer. Komunikatif merupakan salah satu tujuan yang harus dicapai dalam menggeluti suatu pekerjaan tertentu begitu pula dengan jenis pekerjaan sales. Karena dalam dunia sales menggunakan bahasa dalam berkomunikasi itu merupakan kegiatan yang pasti dilakukan dalam proses mencari konsumen atau nasabah. Selain itu kualifikasi kemampuan dalam penggunaan komputer merupakan syarat penting, hal ini menunjukkan bahwa penguasaan teknologi adalah salah satu modal dasar bagi individu untuk dapat bersaing di dunia kerja (Martono, 2010).

Konsep diri dan nilai-nilai merupakan sikap atau perilaku kerja karyawan yang mendukung pencapaian tujuan organisasi. Dari dimensi konsep diri dan nilai-nilai setelah dilakukan penelitian lebih mendalam, ternyata peneliti memperoleh lebih banyak data yang menyatakan konsep diri dan nilai- nilai didalamnya. Banyaknya konsep diri dan nilai-nilai yang didapatkan diperoleh hasil bahwa jujur adalah kualifikasi utama yang harus dimiliki oleh para calon karyawan sales.

Karakteristik pribadi yang dibutuhkan perusahaan untuk karyawan sales adalah mereka calon pelamar dengan jenis kelamin laki-laki maupun perempuan dengan batasan usia maksimal 35 tahun yang berpenampilan menarik serta didukung dengan adanya alat penunjang pekerjaan yaitu kendaraan bermotor yang dilengkapi dengan surat ijin mengemudi. Hasil penelitian tentang jenis kelamin yang dibutuhkan dalam dunia kerja juga telah dipaparkan oleh Martono (2010) yang menyatakan bahwa sebagian besar lowongan kerja memberikan kesempatan yang sama untuk laki-laki maupun perempuan dalam mencari kerja. Kemudian berpenampilan menarik merupakan salah satu hal yang dibutuhkan dalam kriteria menjadi sales, karena seperti yang telah kita ketahui bahwa pekerja sales merupakan pekerjaan yang bertatap muka langsung dengan konsumen, sehingga menarik adalah syarat utama untuk bekerja dibidang sales (Stefanie dan Indriyani, 2014).ada juga beberapa perusahaan yang mencantumkan domisili serta kesehatan fisik calon karyawan dalam kualifikasi kompetensi di dalamnya

Dari hasil penelitian yang telah didapat dapat disimpulkan bahwa menyukai tantangan merupakan motif utama yang dimiliki calon karyawan dibidang sales, selain menyukai tantangan, menyukai target juga harus menjadi motif pendukung didalamnya, karena dalam memperoleh target pasti ada tantangan-tantangan yang akan dihadapi. Arganingrat dan Sadewo (2016) mengatakan bahwa bekerja dibawah tekanan harus dijalani oleh sales, karena karyawan dituntut oleh perusahaan untuk bekerja dalam mencapai target per bulan.

\section{Penutup}

Berdasarkan hasil pembahasan yang telah dipaparkan pada bab sebelumnya mengenai apa saja kompetensi yang 
dibutuhkan perusahaan untuk karyawan bagian sales, maka pada bab ini ditarik beberapa kesimpulan atas analisis tersebut. Pada penelitian ini telah dikategorikan indikator kompetensi menjadi lima dimensi yaitu pengetahuan, keterampilan, konsep diri dan nilai-nilai, karakteristik pribadi serta motif.Pada dimensi pengetahuan didapatkan hasil bahwa untuk kriteria pendidikan yang banyak dicari oleh perusahaan adalah lulusan D3 dan strata SMA, kriteria pengalaman kerja yang banyak dibutuhkanadalah pengalaman minimal 1 sampai 3 tahun di bidang sales dan setelah mengumpulkan lebih banyak data telah ditemukan ada beberapa perusahaan yang telah mencantumkan IPK sebagai kualifikasi di dalamnya namun masih banyak perusahaan yang tidak mencantumkan. Pada dimensi keterampilan didapatkan hasil bahwa yang banyak dibutuhkan dalam dunia kerja salesadalah karyawan yang komunikatif dan mampu mengoperasikan komputer. Pada konsep diri dan nilai-nilai memperoleh hasil bahwa jujur merupakan kualifikasi utama yang harus dimiliki oleh para calon karyawan sales. Pada karakteristik pribadi yang dibutuhkan perusahaan untuk karyawan sales adalah mereka calon pelamar dengan jenis kelamin laki-laki maupun perempuan tanpa memperdulikan status yang disandang calon karyawan dengan batasan usia maksimal 35 tahun yang berpenampilan menarik dan didukung dengan adanya alat penunjang pekerjaan berupa kendaraan bermotor yang dilengkapi dengan surat ijin mengemudi dan ada juga beberapa perusahaan yang mencantumkan domisili serta kesehatan fisik calon karyawan dalam kualifikasi kompetensi di dalamnya. Kemudian dari hasil penelitian juga telah mendapatkan hasil bahwa menyukai tantangan merupakan motif utama yang dimiliki calon karyawan dibidang sales, selain menyukai tantangan, menyukai target juga harus menjadi motif pendukung didalamnya.
Setelah dilihat dari semua pembahasan beserta hasil yang telah diteliti dapat disimpulkan bahwa kompetensi-kompetensi yang diminta untuk karyawan bagian sales tidak ada yang baru diluar dari Palan (2007).

\section{Implikasi Terapan}

Dalam hasil dan pembahasan telah disebutkan bahwasanya pengalaman yang diminta perusahaan minimal 1 sampai 3 tahun dan kurang berminat untuk menerima para pelamar yang fresh graduate atau yang belum memiliki pengalaman. Selain memberikan kesempatan bagi para calon karyawan yang berpengalaman, tidak ada salahnya jika untuk kedepannya perusahaan memberikan kesempatan bagi para fresh graduate serta mereka yang belum memiliki pengalaman untuk melamar dan mengikuti training terlebih dahulu. Karena tidak semua kemampuan seseorang bisa diukur dengan lama pengalaman yang telah didapat sebelumnya. Yang terpenting untuk tercapainya tujuan perusahaan yaitu memiliki karyawan yang niat dan mau berusaha sehingga tujuan atau target akan terpenuhi. Dari hasil penelitian juga didapatkan hasil bahwa maksimal umur yang banyak dibutuhkan perusahaan adalah karyawan sales yang memiliki umur kurang dari 35 tahun, namun bisa dilihat dari penelitian yang telah dilakukan oleh (Ramadhan, 2013) menyatakan bahwa usia produktif tenaga kerja berada pada umur 20 sampai 40 tahun. Yang dimana telah disebutkan bahwa pada usia dibawah 20 tahun rata-rata individu masih belum memiliki kematangan skill yang cukup selain itu juga masih dalam proses pendidikan. Sedangkan usia diatas 40 tahun mulai terjadi penurunan kemampuan fisik bagi individu. Oleh sebab itu tidak ada salahnya jika maksimal umur untuk karyawan sales yang semula maksimal 35 tahun dinaikkan batasnya menjadi maksimal 40 tahun.

\section{Daftar Pustaka}

Arganingrat, Yessi dan Sadewo, FX Sri. 2016. Pilihan Rational Sales PT Sinar Mitra Sentosa Finance dalam Mendapatkan Gaji Tambahan di Sidoarjo. Paradigma, Vol.04 No.03. 
Bennet, R. 2002. Employer's Demands for Personal Transferable Skills in Graduates: a content analysis of 1000 advertisements and an associated empirical study.Journal of Vocational Education \& Training. 54(4): 457-476.

Bulaeng, A. 2004. Metode Penelitian Komunikasi Kontemporer. Yogyakarta: Andi Offset.

Kennan, M. A., Cecez-Kecmanovic, D., Willard, P., and Wilson, C. S. 2007. IS Early Career Job Advertisements: A Content Analysis. 11 $1^{\text {th }}$ Pacific-Asia Conference on Information Systems, pp. 342-353.

Kessler, R. 2011. Competency Based Performance Reviews Evaluasi Kinerja Karyawan untuk Mencapai Sasaran Strategi Organisasi. Jakarta: PPM.

Kholil, S. 2006. Metodologi penelitian. Bandung: Citapusaka Media.

Lupiyoadi. 2013. Manajemen Pemasaran Jasa: Berbasis Kompetensi. Jakarta: Salemba Empat.

Mardianto. 2014. Optimizing Recruitment Strategy Recruitment Management. Jakarta: Pinasthika.

Martono, Nanang. 2010. Karakteristik Lapangan Pekerjaan (Analisis Isi Iklan Lowongan Kerja di Media Surat Kabar. Jurnal Pendidikan dan Kebudayaan. Vol 16, No. 6 Nopember 2010, Balitbang Kemendiknas.

Marwansyah. 2012. Manajemen Sumber Daya Manusia. Edisi Kedua. Alfabeta: Bandung.

Mondy, R. Wayne. 2008. Manajemen Sumber Daya Manusia. Jilid 1 Edisi 10. Jakarta: Erlangga.

Nawawi. 2003. Manajemen Sumber Daya Manusia untuk Bisnis yang Kompetitif. Yogyakarta: Gadjah Mada.

Noe, R. Hollenbeck, J. Gerhart, B. dan Wright, P. 2013. Manajemen Sumber Daya Manusia: Mencapai Keunggulan Bersaing. Jakarta: Salemba Empat.

Palan. 2007. Competency Management Teknik Mengimplementasikan Manajemen SDM Berbasis Kompetensi Untuk Meningkatkan Daya Saing Organisasi. Jakarta: PPM.

Purnomo, T. 2013. Recruitment Online (E-Recruitment) sebagai suatu inovasi dalam perekrutan perusahaan. Jurnal JIBEKA. Vol.7 No.3: 54-59.

Ramadhan, Syaiful Rizal. 2013. Analisis Faktor-Faktor Yang Mempengaruhi Produksi Pada Tenaga Kerja (Studi Kasus CV. Mukkadimah Agro Medica Desa Sawahan Kecamatan Turen Kabupaten Malang).Jurnal Ilmiah Mahasiswa FEB. Vol.1 No.2

Santana, K. 2010. Menulis Ilmiah: Metodologi Penelitian Kualitatif. Jakarta: Yayasan Pustaka Obor Indonesia.

Sarwono, J. 2006. Metode Penelitian Kuantitatif \& Kualitatif. Yogyakarta: Graha Ilmu.

Stefanie, Lisa dan Indriyani, Ratih. 2014. "Studi Deskriptif Proses Rekrutmen, Seleksi Dan Penempatan Karyawan Pada PT MASTRADA SURYA”. AGORA. Vol.2 No.2.

Sugiyono. 2012. Memahami Penelitian Kualitatif. Bandung: Alfabeta.

, 2013. Metode Penelitian Kuantitatif, Kualitatif Dan R \& D. Bandung: Alfabeta.

Sutrisno, E. 2009. Manajemen Sumber Daya Manusia. Jakarta: Kencana.

Thompson, Steven K. 2012. Sampling. Third Edition. USA: John Wiley \& Sons, Inc. P. 60. 
Y. Ayalew, Z. A. Mbero, T. Z. Nkgau, P. Motlogelwa, A. Masizana-Katongo. 2011. Computing knowledge and Skills Demand: A Content Analysis of Job Adverts in Botswana. (IJACSA) International Journal of Advanced Computer Science and Applications, Vol. 2 No.1. 